УДК 006.06
DOI 10.36910/6775-2313-5352-2020-17-10
Карась B.I., Драган А.П., Клендій M.I.
ВП НУБіП України «Бережанський агротехнічний інститут»

\title{
ДО ПИТАННЯ СТАНДАРТИЗАЦІЇ ЕЛЕКТРОМОБІЛІВ В УКРАЇНІ
}

В даній статті проаналізовано проблеми, щзо виникають під час створення, розвитку виробництва і ринку електромобільного транспорту в Україні і світі. Наведено дані щодо темпів розвитку ринку електромобілів в Украйні і світі. Проведено аналіз існуючих стандартів в галузі виробництва і експлуатації електромобілів і окреслено шляхи подальшого розвитку стандартизачії в даній галузі.

Розвиток ринку електромобілів формуе кілька корисних факторів, а саме екологічний, соціально-психологічний, інноваиійний, енергетичний та економічний. Однією із проблем, щяо гальмує розвиток ринку транспортних засобів з електромотором в Україні, є неврегульоване питання обладнання місиь для паркування та зарядки електромобілів, відсутність відповідних дорожніх знаків і т.д. Вирішення иих питань повинно здійснюватися на державному рівні $i$ врегульовуватись нормами і правилами, встановленими у відповідних законодавчих актах та нормативно-технічних документах.

Ключові слова: стандартизачія, електромобіль, електромобілебудування.

Bcmyn. Розвиток світової економіки веде до збільшення кількості транспортних засобів, левову частку яких складають автомобілі. Використання автопарку значно підвищує рівень атмосферного забруднення навколишнього середовища. Контроль за відпрацьованими газами автомобілів і зменшенням викидів шкідливих речовин $\epsilon$ глобальною проблемою і тому встановлюються допустимі норми, що регламентують рівні викидів токсичних речовин. Одним із напрямків вирішення цієї проблеми $є$ впровадження в експлуатацію електромобілів, які значно екологічно безпечніші від автомобілів з двигуном внутрішнього згорання.

Постановка проблеми. Сучасні технічні розробки та науково-обгрунтовані пропозиції в галузі автомобілебудування дають можливість створювати нові машини на базі електричних двигунів, які поступово стають заміною для двигунів 3 традиційними джерелами енергії. Кількість електромобілів в Україні постійно зростає, проте рівень інфраструктури i забезпеченість стандартами відстає і перетворюється на гальмо для розвитку даної сфери.

Аналіз останніх досліджень і публікацій. Хоча, на даний час, в Україні існує досить багато державних стандартів дотичних до виробництва і експлуатації електромобілів [5-11], однак загальний рівень стандартизації у даній галузі не можна вважати достатнім.

Мета статті. Проведення аналізу існуючих стандартів в галузі виробництва i експлуатації електромобілів і окреслення подальшого розвитку стандартизації в даній галузі.

Матеріал досліджень. Сьогодні все більшої популярності набувають екологічно чисті автомобілі. Такі транспортні засоби приводяться в рух електричним струмом, використовуючи або акумуляторні батареї, або паливні елементи, які працюють на водні. Часто в цю категорію включаються і гібридні авто, які використовують електромотори і двигуни внутрішнього згоряння на біопаливі, бензині або дизельному паливі.

Розвиток ринку електромобілів формує кілька корисних факторів, а саме екологічний: покращує екологію навколишнього середовища, знижує рівень викидів вуглекислого газу; соціально-психологічний: проста конструкція електромобіля дає змогу спростити і зробити найбільш зручним його експлуатацію та використання, полегшити ремонт, завдячуючи гальмуванню двигуном, в електромобілів дуже мало зношуються гальма - відповідно, вони порівняно кращі, ніж гальма в звичайних машин, електромобіль не створює сильного шумового забруднення, оскільки його структура містить набагато менше технічних деталей, здатних створювати шум, на відміну від традиційних авто; інноваційний: електромобілі легко захоплюють увагу та стають модною новинкою, навколо них формується потужний кластер роботизації, інноваційних сервісів, ІТ-продуктів, зарядної інфраструктури, використання альтернативних джерел енергії та акумуляторів; енергетичний та економічний: досягнення енергетичної незалежності шляхом створення сонячних ферм чи вітрових електростанцій - це найкраща альтернатива використання російського газу та нафти. Ми можемо збільшити потужності вироблення зеленої енергії, адже в Україні є достатньо відповідних територій. 
В Україні першою розробкою автомобіля 3 електродвигуном вважається 3АЗ-968 Електро, який був розроблений в 1973 році Запоріжським машинобудівним заводом. Автомобіль мав електродвигун потужністю 4 кВт і систему рекуперації енергії — тобто, батареї заряджалися при гальмуванні. Батарея машини важила близько 400 кг, а на одній зарядці «Електрозапорожець» міг подолати 100 км. Його збиралися запустити в серійне виробництво, але фінансування на 3АЗ-968 «Електро» так і не виділили.

Восени 2010 року у Києві вперше представлена нова розробка Запорізького автозаводу ЗАЗ Ланос Пікап Електро. Автомобіль був призначений для обслуговування торговельних точок закритих для руху звичайних автомобілів, зони великих міст, курортів тощо. ЛаносЕлектро оснащений італійським електродвигуном потужністю 15 кВт i вісьмома акумуляторами, які забезпечували пробіг до зарядки орієнтовно 100 км. Один блок акумуляторів українського виробництва розміщений під капотом, інший у вантажному відсіку, де займає близько одного квадратного метру корисної площі. Однак запропонована розробка не була підтримана на державному рівні.

В 2016 році компанія Electric Marathon International презентувала в Монако електромобіль Synchronous. Машину представили як український електромобіль. Дизайн авто виконаний київською студією Prystrast, двигун «Слов'янка» - розробка одеської компанії EcoFactor, виготовлення кузова також проводилося в Одесі. Запас ходу на одній зарядці акумуляторів 130-160 км. На даху автомобіля розміщені сонячні батареї. Synchronous розвиває швидкість 6070 км/год. За словами розробників, зовнішній вигляд, що нагадує середньовічну карету, дозволяє електромобілю стати ідеальним засобом пересування в місті як таксі, або екскурсійне авто. У зв'язку з нестачею фінансування на державному рівні Український автопром поки не створив конкурентоздатний електромобіль, який може вийти на світовий ринок, однак українські інженери за кордоном активно працюють у цій сфері. Одним 3 них є Андрій Джазовський, котрий уже другий рік створює і удосконалює електромобілі, проживаючи в Монако. Розроблена ним модель суперкару HIMERA-Q уже проходить останні випробування в Барселоні; в Україні також планується представлення авто. У червні 2018 року ним також була представлена нова версія концепту Kugel зі зміненим розміщенням сидінь, а також на меншу кількість пасажирів. Електрокар має мотор на 3,3 кВт, що дозволяє подолати відстань у 180-200 км. Kugel замовила влада Монако.

Однак у світі розвиток електромобілебудування, за останні п’ять років, набув шалених темпів зростання. Україна сьогодні є одним з світових лідерів за темпами росту ринку продажів електромобілів. Станом на 30 грудня 2019 року в Україні зареєстровано більше 35 тисяч електромобілів та гібридів, що на 56\% більше, ніж рік тому. В таблиці 1 наведено дані по реалізації автомобілів з електромотором в Україні протягом останніх п'яти років.

Продаж електромобілів в Україні

Таблиця 1

\begin{tabular}{|c|c|c|c|}
\hline Рік реалізації & Електромобілі & Гібридні автомобілі & Разом \\
\hline 2015 & 488 & 216 & 704 \\
\hline 2016 & 1709 & 884 & 2593 \\
\hline 2017 & 3265 & 3084 & 6349 \\
\hline 2018 & 5130 & 4986 & 10116 \\
\hline 2019 & 7687 & 8468 & 16155 \\
\hline
\end{tabular}

Якщо зробити аналіз даних таблиці то побачимо, що за останній рік зріс продаж не тільки електромобілів, але і гібридних машин, реалізація яких в 2019 році вперше перевищила кількість чистих електромобілів.

Аналізуючи графіки реалізації електромобілів і всіх інших транспортних засобів в Україні і світі (див. рис. 1 і 2), можна зробити висновок, що в нашій державі придбання автомобілів з електричним двигуном у процентному співвідношенні до загальної кількості реалізованих транспортних засобів, за останні роки перевищує світові темпи зростання продажів. При цьому необхідно враховувати, що значна кількість транспортних засобів зареєстрованих в Україні не $\epsilon$ новими. Однією із проблем, що гальмує розвиток ринку транспортних засобів 3 електромотором в Україні, $\epsilon$ неврегульоване питання обладнання місць для паркування та зарядки електромобілів, відсутність відповідних дорожніх знаків. 


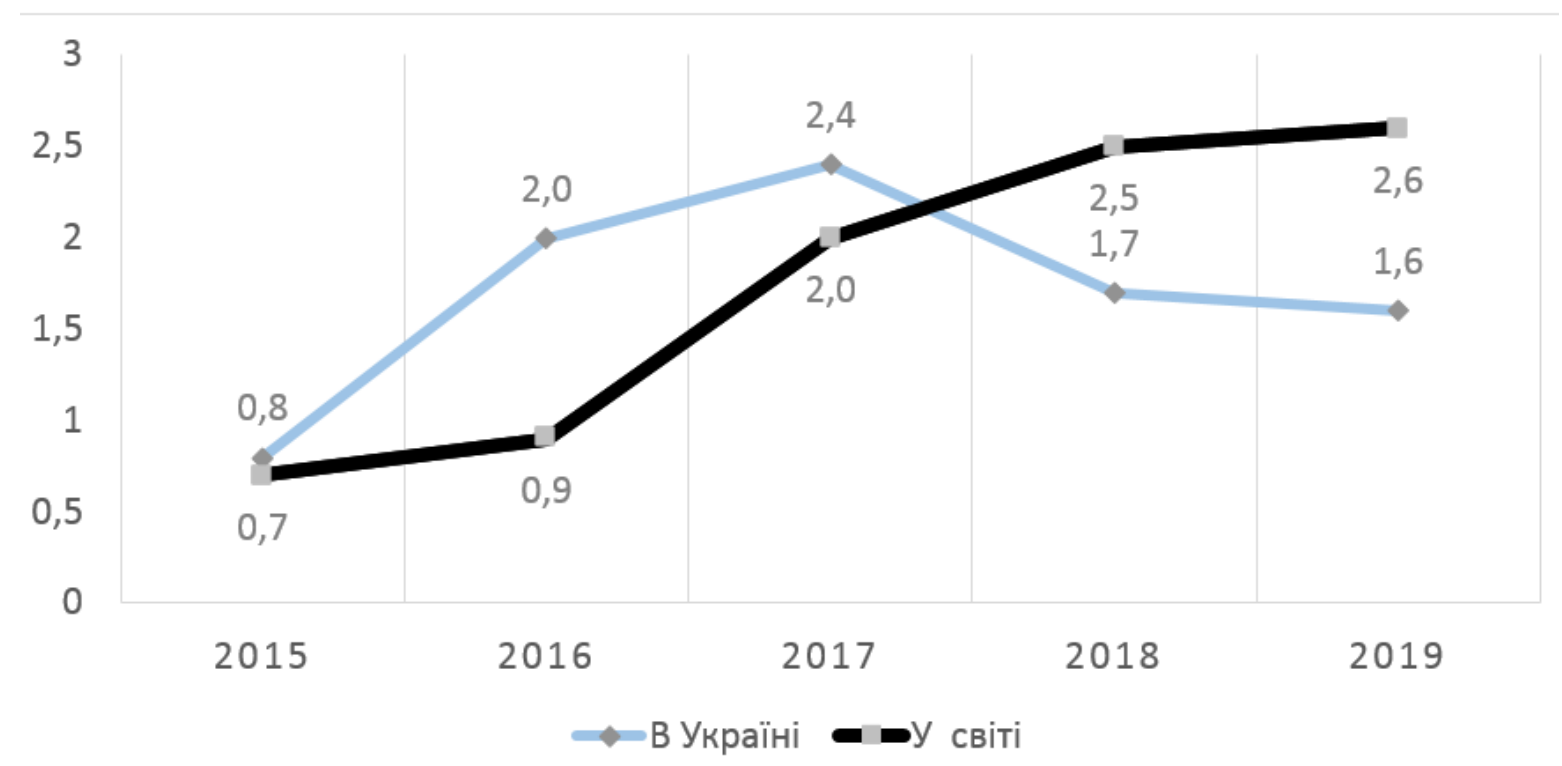

Рис. 1. Процентне співвідношення продажу електромобілів відносно загальної кількості зареєстрованих нових автомобілів

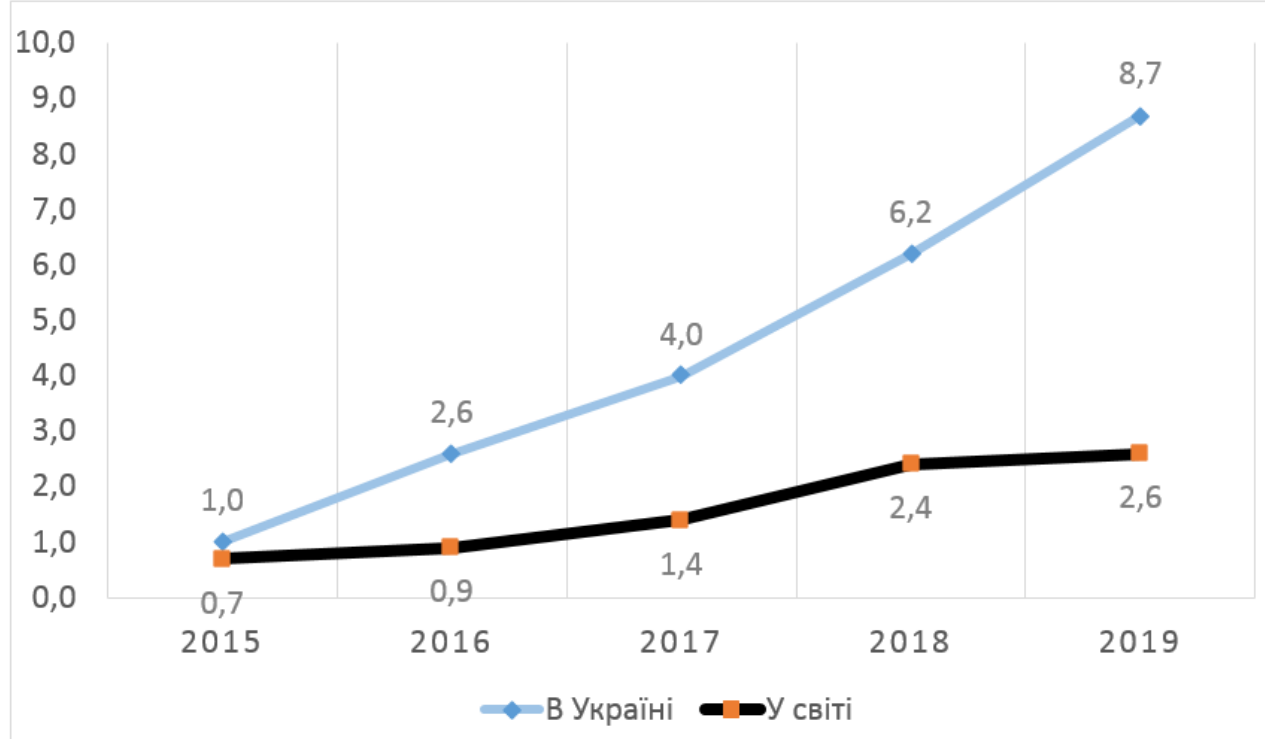

Рис. 2. Процентне співвідношення загально придбаних автомобілів на протязі року в Україні і світі до кількості куплених електромобілів

Вирішення цих питань повинно здійснюватися на державному рівні і врегульовуватись нормами і правилами, встановленими у відповідних законодавчих актах та нормативнотехнічних документах.

Адже, інфраструктура - ключовий елемент у розвитку будь-якої галузі чи сектору економіки. Для електромобільного транспорту розгалужена мережа зарядної інфраструктури $\epsilon$ запорукою комфортного використання електромобілів 3 можливістю пересуватись не лише в межах населених пунктів, але і здійснювати міжміські подорожі. Тому створення нової інфраструктури 3 надшвидкісними зарядними станціями, що також відкриє новий напрямок туризму на електрокарах Для цього потрібні зміни в державних стандартах України, а саме:

- зміни до ДСТУ 4278:2006, які передбачатимуть спеціальні номерні знаки із зеленим кольором шрифту для транспортних засобів, які приводяться в рух електричним двигуном і не мають двигуна внутрішнього згоряння;

- зміни до ДСТУ 4100:2014, які передбачатимуть запровадження нових дорожніх знаків «Для електромобілів», «Крім електромобілів», «Станція зарядки електромобілів»;

- зміни до Державних будівельних норм (ДБН) України щодо визначення обов'язкових параметрів, деталізованих вимог облаштування машиномісць або паркомісць для транспортних засобів, оснащених електричними двигунами (одним чи декількома). Особливо значущими 
мають стати зміни до ДБН України, які мають врегулювати питання будівництва паркувальних майданчиків 3 зарядними станціями для транспортних засобів оснащених електричними двигунами.

На міжнародному рівні розвиток стандартизації, в напрямку забезпечення прискорення електромобілебудування, також не стоїть на місці. Розробка та впровадження нових нормативних документів в світі стане орієнтиром для розвитку випереджаючої стандартизації в Україні. Так в Україні прийняті гармонізовані стандарти ДСТУ EN 60622:2016 і ДСТУ ЕN 60285:2016, які передбачені в рамках реалізації проекту Тwinning «Впровадження системи управління відходами електричного та електронного обладнання (ВEЕО) в Україні».

Впровадження стандартів розроблених міжнародними організаціями із стандартизації сприяє розвитку зарядної інфраструктури електромобілів, а саме IEC 62192-2, який визначає типи електричних роз'ємів і режими зарядки електромобілів. Стандартом визначені три типи електричних роз'ємів і чотири види режиму зарядки акумуляторів електромобілів, що значно підвищить уніфікованість та стандартизацію електричних роз'ємів, конструктивних їх елементів та деталей. ISO 6469-3:2011 встановлює вимоги безпеки електричних двигунів та допоміжних електричних систем.

Ще один стандарт у цій сфері, який допоможе визначити силу тяги, яку очікують автомобілісти - ISO 20762:2018 "Дорожньо-транспортні засоби з електроприводом. Визначення потужності для приведення в рух гібридного електромобіля". Він був розроблений для спрощення процесу оцінки максимальної потужності гібридного електричного транспортного засобу.

Крім того, в даний час розробляється стандарт ISO 23274-1 "Гібридно-електричні дорожні транспортні засоби. Вимірювання викидів вихлопних газів і витрати палива. Частина 1: Транспортні засоби без зовнішньої підзарядки". Цей стандарт дозволить зацікавленим сторонам оцінювати рівень викидів вихлопних газів при різних циклах роботи, навантаженнях $\mathrm{i}$ температурах.

Для поширення електротранспорту потрібно виконати дві умови. По-перше, знизити вартість одного 3 найдорожчих елементів електромобіля - батареї. Її здешевлення найкоротший шлях до доступного транспорту. По-друге, для того, щоб електрокари купували, повинна бути добре розвинена інфраструктура розміщення станцій зарядки.

Одним словом, електромобілі та інші засоби для транспортування на електробатареях (електровелосипеди, електромотоцикли, електросамокати та інші) - це поштовх до розвитку та економічного зростання. З'являються все нові різноманітні пропозиції від банків з вигідними та доступними кредитами на електромобілі. Податкові заходи $є$ також важливим інструментом у формуванні споживчого попиту на електромобілі. Зокрема, у ст. 19 Директиви ЄС передбачено, що Рада ЄС може дозволити податкові пільги при формуванні внутрішнього ринку електромобілів [4].

Також в найближчому майбутньому буде створена нова інфраструктура 3 надшвидкісними зарядними станціями, що також відкриє новий напрямок туризму на різноманітних видах електротранспорту.

Висновки. На основі даних, наведених в даній статті, можна зробити наступні висновки:

- ринок електромобілів $є$ надзвичайно перспективним і у найближчі роки продовжить стрімко розвиватися;

- для забезпечення розвитку ринку електромобілів в Україні необхідно оперативно модернізувати систему стандартів реагуючи на постійні зміни як в технологіях виготовлення електромобілів так і в забезпеченні необхідної інфраструктури і умов їх експлуатації.

\section{Інформаційні джерела:}

1. Гутаревич Ю. Ф. Екологія та автомобільний транспорт: Навчальний посібник / Ю. Ф. Гутаревич, Д. В. Зеркалов, А. Г. Говорун, А.О. Корпач, Л.П. Мержиєвська // - К. : Арістей, 2006. -292 c.

2. Клименко М.О. Метрологія, стандартизація і сертифікація в екології: Підручник. / М.О. Клименко, П.М. Скрипчук // К.: Видавничий центр “Академія”, 2006. - 368 с.

3. Малиш Н. А. Формування та розвиток електромобільної галузі в Україні / Н.А. Малиш // Зелена економіка: перспективи впровадження в Україні : матеріали Міжнародної конференції 
(Київ, 24-25 квіт. 2012 р.) :у 3 т.- К. : Центр еколог. освіти та інформації, 2012. - Т. 1. - С. 240 244.

4. Директиви Європейського Союзу 2003/96/СС «Про реструктуризацію системи Співтовариства 3 оподаткування продуктів енергії та електроенергії». (Офіційний вісник $\mathrm{CC}, \mathrm{L}$ 283, 31 жовтня 2013 р., с. 51-70)

5. ДСТУ IEC 61238-1-3:2019 (IEC 61238-1-3:2018, IDT) Опресовані та механічні з'єднувачі для силових кабелів. Частина 1-3. Методи випробування та вимоги до опресованих та механічних з'єднувачів для силових кабелів для номінальних напруг від 1 кB ( $\mathrm{Um}=1,2 \mathrm{\kappa B})$ до 30 кB $(\mathrm{Um}=36 \mathrm{\kappa B})$, випробуваних на неізольованих провідниках. [Чинний від 2020-01- 01]. Вид. офіц. Київ : ДП «УкрНДНЦ», 2019.- 81 с.

6. ДСТУ EN 60622:2016 Акумулятори та акумуляторні батареї, які містять лужні чи інші некислотні електроліти. Герметизовані нікель-кадмієві призматичні одиночні акумулятори, що перезаряджаються (EN 60622:2003, IDT)[діє від 01.11.2016] Київ: ДП «УкрНДНЦ»,. 2016.-27с.

7. ДСТУ EN 60285:2016 Акумулятори та батареї лужні вторинні. Герметизовані нікелькадмієві циліндричні одиночні акумулятори, що перезаряджаються (EN 60285:1994, IDT) [діє від 01.11.2016] Київ: ДП «УкрНДНЦ»,. 2016.-21с.

8. ДСТУ ЕN ISO 11664-2:2018 (EN ISO 11664-2:2011, IDT; ISO 11664- 2:2007, IDT) Колориметрія. Частина 2. Джерела світла, стандартизовані МКО. [діє від 01.10.2018] Київ: ДП «УкрНДНЦ»,. 2018.-31с.

9. ДСТУ 4278:2019 Дорожній транспорт. Знаки номерні транспортних засобів. Загальні вимоги. Правила застосування. Національний стандарт України [діє від 16.03.2020] Київ: 2019.$23 \mathrm{c}$.

10. ДСТУ ISO 3929:2019 Дорожні транспортні засоби. Методи вимірювання газів під час огляду або технічного обслуговування (ISO 3929:2003,IDT). [діє від 01.09.2019] Київ: ДП «УкрНДНЦ»,. 2019.-36с.

11. ДСТУ4100:2019 Знаки дорожні. Загальні технічні умови. Правила застосування. Національний стандарт України [діє від 16.11.2020] Київ: ДП «УкрНДНЦ»,. 2019.-195с.

12. ISO 6469-1:2019 Electrically propelled road vehicles — Safety specifications — Part 1: On-board rechargeable energy storage system (RESS).

13. ISO 6469-2:2018 Electrically propelled road vehicles — Safety specifications — Part 2: Vehicle operational safety means and protection against failures.

14. ISO 23828:2013 Fuel cell road vehicles - Energy consumption measurement — Vehicles fueled with compressed hydrogen.

15. ISO 6469-3:2018 (en) Electrically propelled road vehicles — Safety specifications — Part 3: Electrical safety.

16. ISO 20762:2018 (en) Electrically propelled road vehicles — Determination of power for propulsion of hybrid electric vehicle.

17. IEC 62192:2009 Live working - Insulating ropes.

18. ISO 23274-1:2019 Hybrid-electric road vehicles — Exhaust emissions and fuel consumption measurements —Part 1: Non-externally chargeable vehicles.

Карась В.И., Драган А.П., Клендий М.И.

ОП НУБиП Украины «Бережанский агротехнический институт»

\section{К ВОПРОСУ СТАНДАРТИЗАЦИИ ЭЛЕКТРОМОБИЛЕЙ В УКРАИНЕ}

В данной статье проанализированы проблемь,, возникающие при создании, развитии производства и рынка электромобильного транспорта в Украине и мире. Приведены данные по темпам развития рынка электромобилей в Украине и мире. Проведен анализ существующих стандартов в области производства и эксплуатации электромобилей и намечены пути дальнейтего развития стандартизаиии в данной отрасли.

Развитие рынка электромобилей формирует несколько полезных факторов, а именно экологический, социально-психологический, инновационный, энергетический и экономический. Одной из проблем, которая тормозит развитие рынка транспортных средств с электромотором в Украине, является урегулирование вопроса оборудования мест для парковки и зарядки электромобилей, отсутствие соответствующих дорожных знаков и т.д. Решение этих вопросов должно осуществляться на государственном уровне и регулироваться нормами 
и правилами, установленными в соответствующих законодательных актах и нормативнотехнических документах.

Ключевые слова: стандартизация, электромобиль, электромобилестроение.

\section{Karas V.I., Drahan A.P., Klendiy M.I.}

Separated Subdivision of National University of Life and Environmental Sciences of Ukraine «Berezhany agrotechnical institute»

\section{TO THE QUESTION OF STANDARDIZATION OF ELECTRIC VEHICLES IN UKRAINE}

This article analyzes the problems that arise during the creation, development of production and the market of electric vehicles in Ukraine and the world. The data on the rate of development of the electric vehicle market in Ukraine and the world are given. The analysis of existing standards in the field of production and operation of electric vehicles is carried out and ways of further development of standardization in this industry are outlined.

The development of the electric vehicle market creates several beneficial factors, namely environmental, socio-psychological, innovation, energy and economic. One of the problems that hinders the development of the market for vehicles with an electric motor in Ukraine is the settlement of the issue of equipping parking and charging places for electric vehicles, the lack of appropriate road signs, etc. The solution of these issues should be carried out at the state level and be regulated by the norms and rules established in the relevant legislative acts and regulatory and technical documents.

Key words: standardization, electric vehicle, electric vehicle construction. 